\title{
Pre-Service Teachers' Perceptions with Regard to Teaching-Learning Processes
}

\author{
Faysal Özdaş ${ }^{1}$ \\ ${ }^{1}$ Department of Educational Sciences, Mardin Artuklu University, Turkey \\ Correspondence: Faysal Özdaş, Department of Educational Sciences, Mardin Artuklu University, Turkey.
}

Received: February 13, 2018

Accepted: March 3, 2018 Online Published: March 20, 2018

doi:10.5539/jel.v7n3p188

URL: https://doi.org/10.5539/jel.v7n3p188

\begin{abstract}
Teaching-learning process has a great important medium where pre-service teachers develop experiences and competences. Pre-service teachers are introduced to this process in a professional sense through the school experience course in teacher training. In this process, it is crucial to identify the encountered difficulties and matters. For this purpose, the perceptions of 48 pre-service teachers attending Pedagogical Formation Training at Mardin Artuklu University and taking the school experience course were got. The study group of the current research consists of the 48 pre-service teachers taking the school experience course in 2014-2015 academic year. The qualitative research method based on the data collection instrument involving two questions in the semi-structured interview form was used. The content analysis was conducted to analyze the data. According to the findings, it was revealed that the pre-service teachers observe or encounter 219 matters with regard to teaching and learning process in the school experience course. It was identified that the most encountered reasons are teacher, school, student related reasons and other ones, respectively. The pre-service teachers developed 229 suggestions to overcome these matters. The findings of this research were compared with the ones in the literature. In this regard, teaching-learning process was discussed.
\end{abstract}

Keywords: teaching-learning processes, pre-service teachers, school experience, Turkey

\section{Introduction}

\subsection{Introduce the Problem}

Teaching-learning process can be defined as a process where pre-service teachers have experiences and ideas about teaching, learning, teacher, student and even acquire positive and negative ideas for school concept. Pre-service teachers get acquainted with this process through the school experience course. In this process, they observe and start to rule this process by undertaking responsibilities. Curriculum consists of four basic components, namely planning, content, teaching-learning process and assessment and evaluation. This study will dwell on teaching-learning process. This process contains learning approaches, teaching strategies, methods, techniques, physical conditions and tools which contribute to ruling all these elements without facing any problem (Arends, 2014). This process is important for students to acquire cognitive, affective and psychomotor skills when curriculum is conducted as expected.

The fact that students are trained according to the aim of an education system depends on how teachers are competent in their teaching profession (Cydis, 2014). Therefore, reconstructive approaches in education assign new roles to teachers. Teachers are expected to develop good relationships with their students, colleagues, school administration and parents, to constantly improve themselves in their profession. There are two dimensions, namely professional ethic and knowledge to train pre-service teachers in a professional sense. They are also required to be competent in content knowledge, pedagogical courses and general cultural courses in their pre-service teacher training program to carry out their teaching practices professionally (Özden, 2005). The most important component in education is teacher. Education basically depends on teachers regardless of training patterns or models (Erdoğan, 2009). Therefore, teachers should be given opportunities to continuously improve themselves in both pre-service and in-service training programs. One of the most important guides for teachers in these processes is the curriculum. Planning teaching process based on a curriculum is assumed to increase efficiency in education with respect to quality (Stewart, 2012). 
The curriculum developed by the Ministry of National Education (MEB) is known to be student-centered. In a student centered approach, students actively participate in the lessons. On the other hand, teaching-learning process in a teacher-centered approach generally focuses on conveying knowledge to students and this knowledge is memorized by students to be remembered in the exact way later. Learning activities to develop thinking and problem solving skills are not much included in this process (Saban, 2014). In traditional learning systems, teaching with a group or one type of teaching is at the forefront. However, nowadays, it is known that learning is special for an individual just like his/her fingerprint special to him/her (Sakiz, 2017). It is recognized that students have different learning styles, interests and intelligences even though they are at the same age or in the same grade. On the other hand, pre-service teachers in education faculties should be closely concerned with technology-based teaching in the technological era in which we live (Angeli, 2005). It is known that those teachers who can successfully integrate technology into teaching can achieve success more easily and fast. Therefore, it is thought that it is more useful to arrange teaching practice courses at education faculties considering the integration of technology into courses (Oigara \& Wallace, 2012). It is considered that teacher has a significant impact on the implementation of a student centered curriculum. To what extent teacher is familiar with the curriculum and eager to conduct it have a decisive role in implementing it successfully (Bulut, 2008). When the current curricula are evaluated, it is seen that students are at the center of the learning process. The basic aim of these curricula is to "prepare individuals for life with having responsibility, being able to think critically and highly skilled in problem solving and decision making" (MEB, 2017). Students should keep teaching-learning process by learning actively and practicing and studying with individual or groups to acquire the mentioned skills and characteristics.

Teacher qualities determine the efficiency of a teaching-learning process. Students' characteristics such as their success, selection of vocations, perspectives on life, life philosophies, respect to others, tolerance are closely related with teacher qualities (Yapıc1, 2015). Education quality is directly associated with what teachers do (Kunter et al., 2013). It is known that all components in education system are important to conduct education and training activity. However, teacher precedes the other components. Because teacher undertakes significant roles such as coordinating the components, selecting appropriate teaching methods and techniques, being successful in human relationships and motivating students. Therefore, teacher has a strategic role to realize education and training objectives (Yavuz \& Karadeniz, 2009).

Teaching-learning process, in one sense, states a student's experience process (Akpınar, 2013). The experiences in the teaching-learning process should be arranged effectively to enable students to develop the expected behaviors from themselves (Woolfolk-Hoy \& Weinstein, 2006). In other words, it is necessary to know how learning occurs and specify definite criteria to organize these experiences. Therefore, education can express learning experiences setting from the perspective of a student and teaching setting from the perspective of a teacher. Learning activities in accordance with the objectives in a student centered process should be planned and learning experience setting should be prepared according to this (Demirel, 2015).

\subsection{The Purpose and Importance of the Research}

It is argued that pre-service teachers need general cultural knowledge, content knowledge and pedagogical knowledge throughout their professional teaching life. Not only theoretical knowledge but also school experience training should be included in teacher training (Özenç, 2014). In other words, pre-service teachers need to take school experience courses, thereby acquiring teaching experiences and developing positive behavior to conduct their teaching effectively. Pre-service teachers' perceptions with regard to teaching-learning process in the school experience course where the mentioned objectives are aimed to be realized, were examined in the current research and they were asked to elicit the matters they encountered in this course where they get teaching experience in real classroom environment. In this context, the purpose of the research is to identify pre-service teachers' perceptions with respect to teaching-learning process in the school experience course. Based on this purpose, the answers for the following questions were sought:

1) What are the matters the pre-service teachers observed or encountered in the school experience course?

2) What are the suggestions of the pre-service teachers for the matters the pre-service teachers observed or encountered in the school experience course?

\section{Method}

\subsection{Research Design}

In this study, program implementation, a type of case study, in qualitative research design was used. Program implementation case study helps understand whether the implementation complies with its purpose. This study is 
useful when there is anxiety of teaching-learning process with regard to the implementation problems. Revealing the comprehensive and longitudinal changes in the implementation in time can provide a context to interpret the findings of the implementation variables. Case studies need to be conducted for a good program implementation. Necessary time should be allocated to obtain longitudinal and width data. Generally, more than one working setting or cases are required to answer the research questions (Davey, 1991). For this purpose, a program implementation case study was carried out to identify the pre-service teachers' perceptions for teaching-learning process. The data including their perceptions for the problems they observed or faced in the process and their suggestions to overcome these problems were obtained.

\subsection{Study Group}

The study group of the research consists of the 48 pre-service teachers taking the school experience course in the context with Pedagogical Formation Training in 2014-2015 academic year. The study group was determined through purposive sampling method. Purposive sampling is a sampling approach which enables to study cases which are thought to have rich information thoroughly (Patton, 2002). The reasons to choose this sampling method are that the researcher knows the pre-service teachers and can reach them more easily. A researcher selects the participants into the sampling who are the most appropriate for the purpose of the research in purposive sampling method. In this regard, a part of the most appropriate population is included to study problem (Balc1, 2009).

\subsection{Data Collection Instrument}

The data of the research were obtained from the semi-structured interview form that was created taking into account the experts' views (two associate professors and one assistant professor in the educational sciences) and reviewing the related literature in detail (Bağcioğlu, 1997; Dursun \& Kuzu, 2008; Özenoğlu Kiremit, 2013; Yüksel, 2017). The data collection instrument consists of two questions in the semi-structured interview form. There are some measures to ensure the validity of the interview form. One of these measures is participant confirmation. The participants were chosen on a volunteer basis and they were told that their identities would not be revealed to enable them to give honest responses to the questions. Yıldırım \& Şimşek (2008) indicated that participants' voluntariness is important to render the validity and reliability of a research. Another measure for the validity of the interview form is that the data were collected by conversing the participants face to face thoroughly. The data were compiled from the pre-service teachers at the end of the school experience course. Besides, the fact that researcher analyses data elaborately and explains how to come conclusions is one of the important measures to enable validity in qualitative research (Yıldırım \& Şimşek, 2008).

The validity of the interview form was ensured considering the experts' views. First, the tentative questions for the subject were prepared. The opinions of the three academic members working in the educational sciences department were taken to assess the questions. Based on their suggestions, the questions were revised. The data collection instrument was conducted by interviewing with the participants included in the sampling.

The process of data collection lasted 14 weeks corresponding to the school experience course. Informed consent to conduct the research was taken from the institutions whereby teachers were working. The school experience involved school observation by teachers, interviews with teachers and school managers, and recording data within standardized forms.

\subsection{Data Analysis}

The pre-service teachers' perceptions for teaching-learning process were analyzed through inductive content analysis by two researchers. The coding was created based on the results while each researcher's findings were similar. Based on this similarity, meaningful parts were gathered during the coding process (Miles \& Huberman, 1994; Şimşek \& Yıldırım; 2008). Following the coding process, themes were formed and were indicated with frequency techniques in tables. The obtained data in the research were presented with descriptive approach and frequency values. Of the data, two themes and six sub-themes were attained. The Cohen Kappa values, which calculated the consensus among the data coders with regard to the sub-themes as follows: Teacher-related reasons .77; school-related reasons .85; other reasons .77: student-related reasons 86; suggestions for teachers .71 and suggestions for school administrators .83. According to Viera \& Garrett (2005), the interpretation of the Kappa values indicate .01-.20 slight agreement; .21-40 fair agreement; .41-.60 moderate agreement; .61-.80 substantial agreement; and .81.-1.00 almost perfect agreement. Content analysis method was used to analyze the data. The treatments in content analysis involve gathering similar data under particular concepts and themes, and organize and interpret the data to enable readers to understand (Yıldırım \& Şimşek, 2008). 


\section{Presentation of the Findings}

The obtained findings from the pre-service teachers' perceptions with regard to teaching-learning process were analyzed. They were presented in tables and evaluated. Coding was used when their perceptions were presented. The letters in the coding (PT) indicate the pre-service teacher and the number in the coding his/her order. The findings attained from the pre-service teachers' perceptions with regard to teaching-learning process were summarized in Table 1 and Table 2.

Table 1. The matters the pre-service teachers observed/encountered in teaching-learning process

\begin{tabular}{|c|c|c|}
\hline Theme & Content & $\mathrm{N}$ \\
\hline $\begin{array}{l}\text { Teacher-related } \\
\text { reasons }\end{array}$ & $\begin{array}{l}\text { Teacher centered teaching (27), Student not motivated to his/her lesson (14), Teacher not competent in } \\
\text { pedagogical respect (14), Teacher follows one type of teaching (13), Miscommunication between teacher } \\
\text { and student in class (12), Not activity-based teaching (11), Excessive lessons and homework (9), Ignoring } \\
\text { individual differences (8), Ignoring learning levels (6), Not using time efficiently (6), Transmitting } \\
\text { intensive knowledge (6), Not having a democratic learning environment (5) Using insulting expressions } \\
\text { (3), Teacher comes to lesson unprepared (2), Teachers angry (1), Conducting unfair behavior (1) }\end{array}$ & 138 \\
\hline $\begin{array}{l}\text { School-related } \\
\text { reasons }\end{array}$ & $\begin{array}{l}\text { Lack of material (13), Physical insufficiencies of school/classes (9), Not enabling students to gain } \\
\text { responsibility (5), Not benefitting from technological equipments (5), Counseling services not serve their } \\
\text { purpose(3), Not developing higher order skills (2), not taking care of student's problems(2), Students not } \\
\text { encouraged to read book (1) }\end{array}$ & 40 \\
\hline $\begin{array}{l}\text { Student-related } \\
\text { reasons }\end{array}$ & $\begin{array}{l}\text { Classroom management problems (15), Negative dialogues between teacher and students (12), Students } \\
\text { come to lesson unprepared (5), Overcrowded classes }\end{array}$ & 32 \\
\hline Other reasons & $\begin{array}{l}\text { (4), Curriculum taking into account a standard student profile (2), Socio-cultural differences in class (1), } \\
\text { Subjects elaborate and abundant (1), Student's values not being revealed (1) }\end{array}$ & 9 \\
\hline Total & & 219 \\
\hline
\end{tabular}

In Table 1, the matters the pre-service teachers determined with respect to teaching-learning process are enumerated as teacher-related reasons, school-related reasons, student-related reasons and other reasons. When the table is examined, it is seen that 138 out of 219 reasons are related with teacher. This result equals to $63 \%$ of the determined matters. In this category, the most stated matter is "teacher centered teaching".

PT14 coded pre-service teacher stated this problem as "A curriculum is not implemented based on the students' skills, interests and needs. Mostly, there is a traditional teaching approach. At the end of a subject matter, students are asked whether they understand it. If they do not understand it, it is briefly lectured". A similar perception expressed by PT38 coded pre-service teacher is that "Nowadays, teachers prefer either lecturing or using slights. Lecturing which descends from teacher centered training approach is, nowadays, used as a convenient method for almost all content".

Another emphasized matter in teaching-learning process is miscommunication and negative dialogues between teacher and student. The miscommunication and negative dialogues may cause unexpected student behaviors and unmotivated students. Concerning this matter, PT16 coded pre-service teacher stated that "Teachers fall behind the developments in science and technology. Student usually knows much more than his/her teacher and those students who are aware of this circumstance may be rude to their teacher and this creates tension".

PT25 coded pre-service teacher attributed the matters in teaching-learning process to teacher centered teaching, lack of material, physical insufficiencies of schools and teachers' not being competent in pedagogical respect indicating that "Our classrooms and schools in education and training process are extremely simple and insufficient. Our teachers are insufficient to use technology and material. Although student centered approach is embraced in the curriculum, teacher centered teaching, unfortunately, is applied".

There are pre-service teachers who regard "ignoring differences" as a matter. PT02 coded teacher remarked this matter as "Standard teaching is applied to those students who have learning disability or special considerations".

A similar perception was indicated by PT01 coded pre-service teacher that "Those students who are particularly unsuccessful, and have different interests and behavioral problems are not taken care of and they get isolated".

Another matter encountered in teaching-learning process is that teaching is conducted in standard classrooms. This matter is emphasized to hinder conducting different activities. To illustrate, PT06 coded pre-service teacher stated that "The same classroom is always used. Different activities are not carried out". 
PT37 coded pre-service teacher criticizes the curriculum and expresses that it standardizes the methods and techniques indicating that "The fact that the curriculum is standard standardizes the methods and techniques used in teaching-learning process". PT07 coded pre-service teacher regard "Over permissiveness provided to students in classes make it hard to manage and control classroom" as a matter.

The suggestions for the matters the pre-service teachers observed or encountered in teaching- learning process in the school experience course with regard to the second sub-problem were presented in Table 2.

Table 2. The suggestions for the matters the pre-service teachers observed or encountered in teaching-learning process

\begin{tabular}{|c|c|c|}
\hline Theme & Content & $\mathrm{N}$ \\
\hline $\begin{array}{l}\text { Suggestions for } \\
\text { teachers }\end{array}$ & $\begin{array}{l}\text { Constructive approach should be taken into account (23), Student should be motivated to his/her lesson } \\
\text { (22), Active teaching methods and techniques should be used (22), Rote learning should be left (15), } \\
\text { Teacher student communication should be open (13), Individual differences should be paid attention (13), } \\
\text { Activities should be determined according to students' interest, needs and abilities (10), Students' } \\
\text { readiness level should be paid attention (9), Benefitting from electronic devices in classes (Smart board, } \\
\text { projection etc.) (9), Teacher should associate the current lesson with the previous one ( } 8 \text { ), Learning by } \\
\text { practicing, how to access to knowledge should be taught ( } 8 \text { ), Different materials should be used (8), } \\
\text { Indiscipline behaviors in classes should be prevented (6), Excessive homework should not be assigned (5), } \\
\text { Learning should be simplified (5), Cultural structure should be taken into account ( } 4 \text { ), Teacher should be } \\
\text { patient and tolerant (4), Teacher should come to lesson prepared (4), Students should be treated equally } \\
\text { (3), Democratic classroom environment should be created ( } 3 \text { ), Different places for teaching should be } \\
\text { preferred (2), Students should be acquired a sense of responsibility (2), Teacher should teach in the context } \\
\text { with his/her lesson plan (2), Student should be provided a sense of value (2) }\end{array}$ & 202 \\
\hline $\begin{array}{l}\text { Suggestions for } \\
\text { school } \\
\text { administrators }\end{array}$ & $\begin{array}{l}\text { Physical infrastructure and equipment matters should be overcome (9), Curriculum should be introduced (5), } \\
\text { Students should care pre-service and in-service training (4), Student's learning should be guided (4), Parents } \\
\text { should be made contact (4), Artistic and sportive activities should be conducted (1) }\end{array}$ & 27 \\
\hline Total & & 229 \\
\hline
\end{tabular}

When Table 2 is examined, it is seen that 229 suggestions were developed for the matters in teaching-learning process. 202 out of 229 suggestions were put forward for teachers. This result equals to about $88 \%$ of the suggestions. Some of the suggestions developed by the pre-service teachers with regard to the matters encountered/observed in teaching-learning process were enumerated below. When the developed suggestions are considered, it is understood that pre-service teachers attach more importance to the suggestions involving student centered approach. In this regard, PT32 coded pre-service teacher stated that "Teachers still use behaviorist approach in teaching process. All teachers need to embrace constructive approach". A similar view was stated by PT16 coded pre-service teacher that "Material should be used in lesson, constant teaching in the same way should be avoided. Utilizing different and convenient techniques for each lesson or subject prevents students from getting bored, increases their attention level and minimizes classroom management problems". PT25 coded pre-service teacher emphasized that individual should be in the center of teaching-learning process indicating that "Conditions and medium should be arranged according to individual by placing him/her in the center of teaching-learning process".

PT37 coded pre-service teacher, who stressed out student centered approach in teaching-learning process and attracted attention to the concept empathy, expressed that "Teaching method and technique should be organized according to student and student should not be regarded as a memory which can be loaded knowledge with a teaching haste. Knowledge should be conveyed to student showing empathy and by the time student understands his/her subject thoroughly, another subject should not be taught".

Another suggestion developed for teaching-learning process is that teacher should pay attention to individual differences. In this regard, PT01 coded pre-service teacher developed such a suggestion: "Students' individual differences should be revealed". On the other hand, PT08 coded pre-service teacher emphasized the use of material in teaching-learning process: "Teacher should not use the same material in every lesson and using different materials will meet student's need and attract his/her attention".

\section{Discussion}

This research tried to identify the matters the pre-service teachers observed/faced in teaching-learning process in the school experience course and the suggestions they presented to solve these matters. When the pre-service 
teachers' perceptions are considered, it is seen that they observed or faced a number of matters and developed the suggestions for the matters.

In the context with the first purpose of the research, the matters the pre-service teachers observed/encountered in teaching-learning process were determined. In this regard, 219 matters were revealed. These matters were grouped under four themes such as "Teacher Related Reasons", "School Related Reasons", "Student Related Reasons" and "Other Reasons". In the general sense, it is seen that the matters mostly stem from teachers. It was indicated in the study conducted by Geçer \& Özel (2012) that teachers largely use traditional teaching methods. Similar findings were obtained in other researches (Solmaz, 2007).

It is understood that more half of the matters pre-service teachers observed/encountered in teaching learning process are concerned with teachers. This result demonstrates the importance of teacher in teaching and learning (Kunter et al., 2013; Shaffer \& Thomas-Brown, 2015). In the sub-theme of teacher related reasons, the matter predominantly originates from teacher centered teaching approach. This finding is supported with other research results. It was concluded in the study implemented by Akpınar \& Gezer (2010) that teachers heavily use lecturing method and do not know sufficiently the prominent strategies and method-techniques used in new approaches in education. In the study conducted by Bulut (2008) it was revealed that the teachers' evaluations for the learning environment where the curriculum is applied with regard to student centered activities is at the "low" level.

Another issue in teaching-learning process is that teachers do not use materials sufficiently. One of the basic duties of a teacher is that he/she utilizes his/her opportunities efficiently and can prepare materials taking into account his/her students' needs (MEB, 2008). However, it was confirmed that pre-service teachers use teacher centered approaches instead of the student centered, activity based and material based teaching and teaching which aims to learn together by exploring in group studies (Eraslan, 2008). In the study conducted by Taşdere (2014) it was found out that teachers teach their subject matter depending on a single source in traditional way and students get knowledge from the source directly and are passive in the process. When the curricula developed based on the constructive approach is examined, students should be responsible for their own learning in teaching-learning process and strategies, method and techniques constantly should be used to make them active. There are other studies in the literature indicating that teachers mostly use teacher-centered methods in teaching-learning process (Baeten, Dochy, Struyven, Parmentier, \& Vanderbruggen, 2016; Öztaş \& Turan, 2009).

Teachers' incompetency in pedagogical respect is another observed matter. All teachers are actually known to have taken pedagogical training. However, such a view was put forward as this training might be at the theoretical level. There can be a number of reasons why this training is at the theoretical level. The most important reason could be teacher employment system because selection and placement exam for teachers and exam for teachers' employment are conducted through multiple-choice exams and the implementation dimension of pedagogical formation training is neglected.

Another matter articulated with regard to teacher related reasons is that teacher is insufficient in time management in teaching-learning process. Time management issue is concerned with planning. Planning or time management issue should be solved to attain the maximum efficiency in teaching-learning process (Sahito \& Vaisanen, 2017). According to Erden (2008), there is a relationship between the effective use of time and the acquisition of the aims. The effective use of time in class depends on well-planned of teaching process, arrangement of out of class activities and effective use of teaching-learning process. A teacher should be able to conveniently use teaching and learning period taking into account lesson chapters and guide his/her students to effectively utilize time in and out of class studies. Besides, he/she should be able to plan method, techniques, activities, lesson equipment and materials, assessment-evaluation techniques with his/her students (MEB, 2008).

It is remarkable to encounter the matter in which individual differences are disregarded or these differences are ignored. The fact that these differences are ignored is on the contrary with one of the principles of the constructive approach where individual differences should be considered in teaching-learning process. According to MEB (2008), teacher comes across students who have different needs, interests and skills. The teacher should know that students have the right to get education, which develop their capacity and increase their options. He/she should be able to consider this issue while planning teaching-learning process. However, in the study conducted by Özenoğlu Kiremit (2013), it was found out that individual differences are not regarded in the teaching-learning process. According to Güven \& Sözer (2007), individual differences taking place in teaching-learning process is an expected case. Nevertheless, it generally constitutes a major problem for teachers to deal with these differences flexibly (Dijkstra, Walraven, Mooij, \& Kirschner, 2016). This result inhibits 
students' participation into lesson to a large extent and makes them passive in lesson. When individual differences and understanding in the current curriculum are taken into account, student centered strategy, method and techniques should be used in teaching-learning process.

In the context with "School Related Reasons" sub-theme, it is seen that pre-service teachers mention about lack of material and physical insufficiencies of schools and classes. The results of the research support these findings. To illustrate, Vatanartıran \& Eren (2014) revealed that schools are insufficient with regard to physical equipment. A similar finding is presented in the study by Akbaba \& Turhan (2016) and Al Azri \& Al-Rashdi (2014). Lack of materials at schools matter can be regarded as a result of teacher centered teaching. The fact that teachers teach at theoretical level may cause pre-service teachers to articulate such a view. Because it is known that the schools included in the research are in the scope of the project "Movement of Enhancing Opportunities and Improving Technology" (FATIH) and they are, at least, equipped with the materials at basic level. Which means that with the FATIH project, the equipment for the school is provided.

Undisciplined behaviors in classes and negative dialogues between teacher and students were perceived as matters by pre-service teachers. The results of the research revealed that undisciplined behaviors cause problems in teaching-learning process (Charles, 2014; Özdaş \& Akpinar, 2016; Çetin, 2013).

In the second purpose of the research, the pre-service teachers' solution recommendations were tackled. In this regard, 229 suggestions were developed. The suggestions were generated under the themes such as suggestions for teachers and school administrators. 202 out of 229 suggestions were related with teachers. Pre-service teachers' suggestions for teaching and learning process as follows: student centered approach should be in the center; active learning method and techniques should be used; student should be motivated to lesson; individual differences should be paid attention.

The pre-service teachers involved in the current research had student centered teaching experiences in the courses, namely Principles and Methods of Instruction, Methods of Teaching for One's Subject Domain, and Instructional Technologies and Material Development. Therefore, they might show more awareness of student centered approaches in the school experience course. The developed suggestions can be originated from the discussions occurred in the theoretical based courses and strategy, method and techniques experienced in the above-mentioned courses.

When an overall evaluation for the whole suggestions is conducted, it can be stated that the pre-service teachers, in fact, define an ideal type of a teacher and a learning environment in the current conditions. It is understood that the suggestions are appropriate for the curriculum. In fact, it is seen that similar expressions appear in the curriculum developed in 2005 and in the completed revision of the curriculum in 2017. For instance, teachers are expected not to be dependent on a single teaching approach, pay attention to individual differences, benefit from a variety of teaching strategy, method and techniques and utilize several teaching strategies to develop students' interests and skills (MEB, 2017).

\section{Recommendations}

Findings of this research have some implications for theory and practice in the field of teacher training and practices. First, teachers need to be equipped with skills that focus on student-centered practices and consider their psychosocial aspects. In addition, in line with the curricula designed by the Ministry of National Education, teachers should be provided with opportunities to practice their knowledge regarding teaching and learning processes. In order to achieve this, the curricula should include content related to teacher-centered approaches, strategies, methods and techniques. To add, these theoretical processes should be practiced in schools with appropriate modeling within the teacher preparation programs and departments in faculties of education. Good practices at the local and national level that illustrate sample teacher and learning practices should be shared with teachers' community. Therefore, student-centered approaches can circulate among more teachers and achieve a higher impact level.

\section{References}

Akbaba, A., \& ve Turhan, M. (2016). İlköğretim okul binalarının fiziksel sorunlarına ilişkin öğretmen görüşlerinin incelenmesi (Van il örneği)". KTÜ Sosyal Bilimler Enstitüsü Sosyal Bilimler Dergisi, 6(12), 341-357.

Akpınar, B. (2013). Eğitimde program geliştirme. Ankara: Data Yayınları.

Akpınar, B., \& ve Gezer, B. (2010). Öğrenen merkezli yeni eğitim yaklaşımlarının öğrenme-öğretme sürecine yansımaları. Dicle Üniversitesi Ziya Gökalp Eğitim Fakültesi Dergisi, 14(2010), 1-12. 
Al Azri, R. H., \& Al-Rashdi, M. H. (2014). The effect of using authentic materials in teaching. International Journal of Scientific \& Technology Research, 3(10), 249-254.

Angeli, C. (2005). Transforming a teacher education method course through technology: Effects on preservice teachers' technology competency. Computers \& Education, 45(4), 383-398. https://doi.org/10.1016/j.compedu.2004.06.002

Arends, R. (2014). Learning to Teach. New York: McGraw-Hill Higher Education.

Baeten, M., Dochy, F., Struyven, K., Parmentier, E., \& Vanderbruggen, A. (2016). Student-centred learning environments: an investigation into student teachers' instructional preferences and approaches to learning. Learning Environments Research, 19(1), 43-62. https://doi.org/10.1007/s10984-015-9190-5

Bağcıŏlu, G. (1997). Genel, mesleki ve teknik eğitim fakültelerindeki öğretmenlik uygulaması dersine ilişskin ögretim elemanı ve öğrenci görüşleri (Unpublished Master's diss). Hacettepe Üniversitesi, Ankara.

Balc1, A. (2009). Sosyal bilimlerde araştırma. Ankara: Pegem Akademi.

Bulut, İ. (2008). Yeni ilköğretim programlarında öngörülen öğrenci merkezli uygulamalara ilişkin öğretmen görüşleri (Diyarbakır ili örneği). Kuram ve Uygulamada Eğitim Yönetimi, 56(2008), 521-546.

Charles, C. M. (2014). Building classroom discipline (11th ed.). Upper Saddle River, New Jersey: Pearson Education.

Cydis, S. (2014). Fostering competencies in future teachers: A competency-based approach to teacher education. Creative Education, 5(13), 1148-1159. https://doi.org/10.4236/ce.2014.513130

Çetin, B. (2013). Sınıfta istenmeyen öğrenci davranışlarıyla ilgili sınıf öğretmenlerinin karşılaştıkları sorunlar ve çözüm önerileri. Ahi Evran Üniversitesi Kırşehir Eğitim Fakültesi Dergisi, 14(1), 255-269.

Davey, L. (1991). The application of case study evaluations. Practical Assessment. Research \& Evaluation, 2(9), $1-2$.

Demirel, Ö. (2015). Eğitimde program geliştirme. Ankara: Pegem Akademi.

Dijkstra, E. M., Walraven, A., Mooij, T., \& Kirschner, P. A. (2016). Improving kindergarten teachers' differentiation practices to better anticipate student differences. Educational Studies, 42(4), 357-377. https://doi.org/10.1080/03055698.2016.1195719

Dursun, Ö. Ö., \& ve Kuzu, A. (2008). Öğretmenlik uygulaması dersinde yaşanan sorunlara yönelik öğretmen adayı ve öğretim elemanı görüşleri. Selçuk Üniversitesi Ahmet Keleşoğlu Eğitim Fakültesi Dergisi, 25(2008), 159-178.

Eraslan, A. (2008). Fakülte-okul işbirliği programı: Matematik öğretmeni adaylarının okul uygulama dersi üzerine görüşleri. Hacettepe Üniversitesi Eğitim Fakültesi Dergisi, 34(34), 95-105.

Erden, M. (2008). Sinlf yönetimi. Ankara: Arkadaş yayınevi.

Erdoğan, İ. (2009). Eğitime dair. Ankara: Pegem Akademi.

Geçer, A., \& Özer, R. (2012). İlköğretim fen ve teknoloji dersi öğretmenlerinin öğrenme-öğretme sürecinde yaşadıkları sorunlar. Kuram ve Uygulamada Eğitim Bilimleri, 12(3), 1-26.

Güven, B., \& ve Sözer, M. A. (2007). Öğretmen adaylarının öğretimin bireyselleştirmesine ilişkin görüşleri. Hacettepe Üniversitesi Ĕ̈itim Fakültesi Dergisi, 32(2007), 89-99.

Kunter, M., Klusmann, U., Baumert, J., Richter, D., Voss, T., \& Hachfeld, A. (2013). Professional competence of teachers: Effects on instructional quality and student development. Journal of Educational Psychology, 105(3), 805-820. http://dx.doi.org/10.1037/a0032583

Miles, M. B., \& Huberman, A. M. (1994). Qualitative data analysis: An expanded sourcebook. Thousand Oaks, CA: Sage.

Ministry of National Education. (2008). Öğretmen yeterlilikleri ögretmenlik mesleği genel ve özel yeterlilikleri. Ankara: Devlet Kitapları Müdürlüğü.

Ministry of National Education. (2017). Ortaögretim türk dili ve edebiyati dersi ögretim programı. Retrieved from http://mufredat.meb.gov.tr/ProgramDetay.aspx?PID=208

Oigara, J. N., \& Wallace, N. (2012). Modeling, training, and mentoring teacher candidates to use smart board technology. Issues in Informing Science and Information Technology, 9(12), 297-315. https://doi.org/10.28945/1623 
Özdaş, F., \& Akpinar, B. (2016). The frequency of unwanted student behaviours in secondary schools in terms of certainvariables. International Journal of Learning and Teaching, 2(1), 43-47. https://doi.org/10.18178/ijlt.2.1.43-47

Özden, Y. (2005). Öğrenme ve öğretme. Ankara: PegemA Yayınları.

Özenç, M. (2014). Temel kavramlar ve yasal çerçeve ve sorumluluklar. In V. C. Aktepe, \& ve E. Yalçınkaya (Eds.), Kuram ve uygulamada okul deneyimi ve ögretmenlik uygulamast. Ankara: Pegem Akademi Yayıncilık.

Özenoğlu Kiremit, H. (2013). Ortaöğretim biyoloji öğretmenlerinin 2007-biyoloji ders programının öğrenme-öğretme süreci ile ilgili görüşlerinin biyoloji öğretmeni özel alan yeterlilikleri ile ilişkisi (Aydın ili örneği). Buca Ĕ̈itim Fakültesi Dergisi, 36(2013), 76-108.

Öztaş, S., \& ve Turan, R. (2009). İlköğretim altıncı sınıf sosyal bilgiler tarih ünitelerinin işlenişinde öğretmenlerin kullandıkları öğretim yöntemleri. Türk Eğitim Bilimleri Dergisi, 7(4), 903-932.

Patton, M. Q. (2002). How to use qualitative methods in evaluation. Newbury Park, CA: Sage.

Saban, A. (2014). Öğrenme öğretme süreci yeni teori ve yaklaşımlar. Ankara: Nobel yayıncıllk.

Sahito, Z., \& Vaisanen, P. (2017). Effect of time management on the job satisfaction and motivation of teacher educators: A narrative analysis. International Journal of Higher Education, 6(2), 213-224. https://doi.org/10.5430/ijhe.v6n2p213.

Sakiz, H. (2017). Students with learning disabilities within the context of inclusive education: issues of identification and school management. International Journal of Inclusive Education.

Shaffer, L., \& Thomas-Brown, K. (2015). Enhancing teacher competency through co-teaching and embedded professional development. Journal of Education and Training Studies, 3(3), 117-125. https://doi.org/10.11114/jets.v3i3.685.

Solmaz, A. (2007). Fen bilgisi ögrretiminde kullanılan öğretim yöntemleri ve yöntemlerin uygulanışına ilişkin ögrrenci görüşleri (Unpublished Master's diss). Gazi Üniversitesi, Ankara.

Stewart, V. (2012). A World Class Education: Learning from International Models of Excellence and Innovation. Alexandria, VA: Association for Supervision and Curriculum Development.

Taşdere, A. (2014). Sınıf öğretmen adaylarının öğretmenlik uygulaması dersine yönelik yaşadıkları sorunlar ve çözüm önerileri. Turkish Studies, 9(2), 1477-1497. https://doi.org/10.7827/TurkishStudies.6254

Vatanartıran, S., \& ve Eren, A. K. (2014). Anadolu Sağlık Meslek Liselerinin Etkili Okul Boyutları Bağlamında İncelenmesi. Adlyaman Üniversitesi Sosyal Bilimler Enstitüsü Dergisi, 7(16), 449-474. https://doi.org/10.14520/adyusbd.540

Viera, A. J., \& Garrett, J. M. (2005). Understanding interobserver agreement. The Kappastatistic. Family Medicine, 37(5), 360-363.

Woolfolk Hoy, A., \& Weinstein, C. S. (2006). Student and teacher perspectives on classroom management. In C. M. Evertson \& C. S. Weinstein (Eds.), Handbook of classroom management (pp. 181-219). Mahwah, NJ: Erlbaum.

Yapıcı, M. (2015). Etkili Öğretmenlik Stratejileri. In İ. Yıldırım (Ed.), Eğitim Psikolojisi (pp. 615- 649). Ankara: Anı Yayıncılık.

Yavuz, C., \& ve Karadeniz C. B. (2009). Sınıf öğretmenlerinin motivasyonunun iş tatmini üzerine etkisi. Uluslararası Sosyal Araştırmalar Dergisi, 2(9), 507-519.

Yıldırım, A., \& ve Simsek, H. (2008). Sosyal bilimlerde nitel araştırma yöntemleri. Ankara: Seçkin Yayıncılık.

Yüksel, N. S. (2017). Öğretmen Adaylarının Uygulama Öğretmeni Değerlendirmelerinin Uygulama Deneyimine Göre İncelenmesi. Elektronik Sosyal Bilimler Dergisi, 16(62), 1048-1062. https://doi.org/10.17755/esosder.293181

\section{Copyrights}

Copyright for this article is retained by the author(s), with first publication rights granted to the journal.

This is an open-access article distributed under the terms and conditions of the Creative Commons Attribution license (http://creativecommons.org/licenses/by/4.0/). 